\title{
David L. Rimoin, MD, PhD 1936-2012
}

David L. Rimoin, a native of Montreal, received his undergraduate degree in genetics and his medical and master of science degrees from McGill University. During his residency in internal medicine in Montreal, he was invited by Victor McKusick to continue his studies at Johns Hopkins Hospital, and he began a fellowship in the emerging field of medical genetics. With Victor as mentor, then and throughout life, Dave produced a $\mathrm{PhD}$ dissertation on the genetics of diabetes mellitus, a notion heretical in the 1960s. His first faculty appointment was at Washington University, where he pursued wide-ranging studies of diabetes mellitus, growth hormone deficiency, short stature in pygmies, skeletal dysplasias, and dysmorphology. In 1970 he accepted a call to the West, to join a nascent program in medical genetics based at Harbor/UCLA Medical Center in Torrance. With close colleagues Larry Shapiro and Michael Kaback, he worked in Quonset huts left over from World War II and built an exceptional program around, among other areas, Tay-Sachs carrier screening and connective-tissue disorders (in particular, skeletal dysplasias). Early trainees and junior associates included Bill Horton, Ilka Kaitala, Jerry Rotter, David Sillence, Jon Zonana, and the late David Hollister. At that time, he also forged his most important collaboration, with Ann Garber, his wife of 32 years.

In 1986 Dave was recruited to Cedars-Sinai Medical Center, where he established training and clinical programs in medical genetics and continued the vaunted International Registry of Skeletal Dysplasias, the latter with Ralph Lachman, Dan Cohn, Bill Wilcox, and Deborah Krakow. At Cedars, he became the Steven Spielberg Professor and Chair of the Department of Pediatrics, as one of an illustrious line of internist-geneticists who led pediatricians. He stepped down from the pediatrics post in 2004 and became director of the Medical Genetics Institute at Cedars. For many years he led the training program in medical genetics that linked UCLA and Cedars.

At the International Congress of Genetics in Moscow in the late 1970s, Dave and Alan Emery conceived Principles and Practice of Medical Genetics, following the lead of William Osler, who authored the first edition of his book, Principles and Practice of Medicine, at Johns Hopkins in 1892. This multiauthored text is entering the sixth edition, steadfastly guided by Dave until the end. ${ }^{1}$

Dave was the recipient of numerous honors, including the Lifetime Achievement Award of the ACMG Foundation last year, the March of Dimes Colonel Harlan Sanders Award, and the E. Mead Johnson Award for Research in Pediatrics. He was

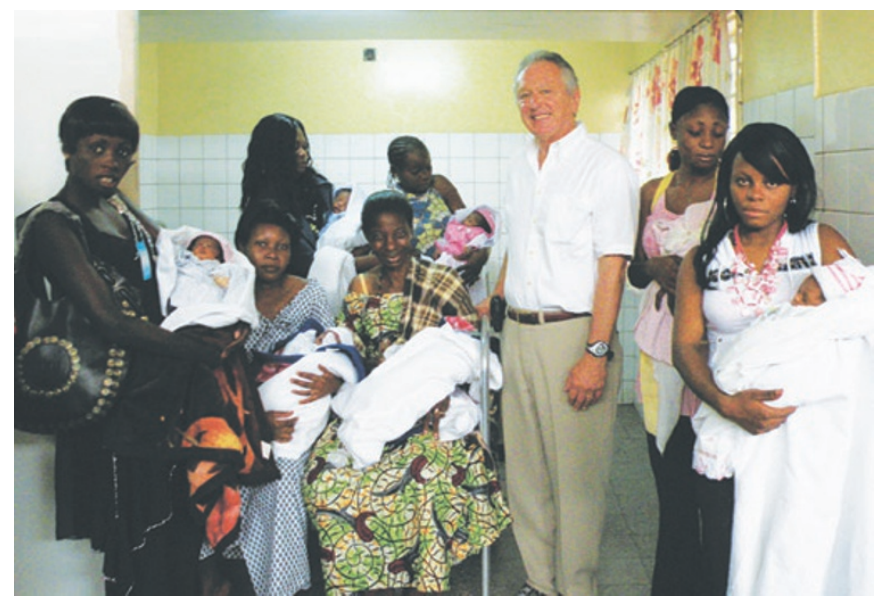

David Rimoin and patients in South Africa.

an elected member of the Association of American Physicians, the Johns Hopkins University Society of Scholars, and the Institute of Medicine of the National Academy of Sciences.

His greatest mark was as a leader. While some in the late 1970s eschewed specialty status for medical geneticists, Dave was one of a small group who founded the American Board of Medical Genetics and served as its first president. He then helped organize the meetings that led to the formation of the ACMG, well documented in his celebration of the twentieth anniversary. ${ }^{2} \mathrm{His}$ six years as the first ACMG president were marked by acceptance of medical genetics into the American Board of Medical Specialties, a singular achievement. During his tenure, he was ably assisted by Sharon Robinson as a part-time administrator, a far cry from the extensive and effective support staff of the ACMG today. Along the way, he was elected president of the ASHG. He served as president of the ACMG Foundation and on its board until this year.

None of us who attended the Association of Professors of $\mathrm{Hu}$ man and Medical Genetics annual meeting with Dave in early May could have predicted the events at the end of the month, least of all Dave himself. He was engaged-enthusiastically describing the program that he built at Cedars-Sinai and UCLA; productive-writing the competitive renewal of his NIH-supported Skeletal Dysplasia Center, which was submitted the day he received his diagnosis; committed-shepherding the sixth edition of Principles and Practice of Medical Genetics through the last tardy authors; vibrant-spending his usual hour in the 
gym each morning and entertaining no thought of retiring; enjoying life-sharing good food and better wine with old and new friends; and enormously proud of his family-especially daughter Annie, who had just achieved tenure at UCLA, son Michael with his MBA, and daughter Lauren, who was to graduate from the Geffen School of Medicine at UCLA the first weekend in June. In literally his last official act, with the UCLA Dean's blessing, he draped Lauren's doctoral hood over her head in the ICU.

He suffered as little as possible, with symptoms of metastatic pancreatic cancer having appeared less than two weeks before his death on 27 May 2012. It is left for his family, friends, and colleagues to suffer his unexpected loss.
Further, it is for us in the profession to carry on the work that he so nobly entrusted to us.

\section{Reed E. Pyeritz, $M D, P h D$}

Departments of Medicine and Genetics, University of Pennsylvania School of Medicine, Philadelphia, USA

\section{REFERENCES}

1. Rimoin DL, Pyeritz RE, Korf BR (eds). Principles and Practice of Medical Genetics, 6th edn. Elsevier: Philadelphia, in press.

2. Rimoin DL. The American College of Medical Genetics, the first 20 years. Genet Med 2011;13:179-187.

doi: $10.1038 /$ gim 2012.79 